DE DE GRUYTER OPEN
Research Article

(C) 2017 Emmanuel Imuetinyan Obarisiagbon. This is an open access article licensed under the Creative Commons Attribution-NonCommercial-NoDerivs License (http://creativecommons.org/licenses/by-nc-nd/3.0/).

\title{
Congregation of the Condemned: Decades of Discontinuous Debates on Death by Design in Southern Nigeria
}

\author{
Barr. Emmanuel Imuetinyan Obarisiagbon, Ph.D
}

\author{
Dept. of Sociology \& Anthropology, \\ Faculty of Social Sciences, \\ University of Benin, Benin City
}

Doi: $10.1515 / m j s s-2017-0045$

\begin{abstract}
The application of death penalty has been a subject of heated arguments amongst scholars, human right proponents and Christian religious leaders. Although several nations the world over have abrogated its use, Nigeria still has death penalty deeply entrenched in its statute books. In spite of this, capital offences are still on the increase thus calling to question, its relevance as a form of deterrent. The study utilised the functionalist theory. The design was exploratory and involved the use of qualitative methods of data collection. Three states: Edo, Delta and Anambra in southern Nigeria were purposively selected due to high incidence of the commission of capital offences in the locations. 1200 questionnaires were administered to respondents, 30 in-depth interviews and 15 key informant interviews were conducted. A descriptive analysis of the quantitative data collected was undertaken using frequency distribution while the manual content analysis was used for qualitative data collected from the field work. Findings from this investigation showed that death penalty does not in any way deter would-be criminals from committing crime. Based on the findings of the study, government rather than eliminating criminals should instead focus more on their rehabilitation and also use its enormous power and resources to redress some of the inequalities and injustice that characterize our society which is often the cause of crime.
\end{abstract}

Keywords: Death penalty, Capital offence, Deterrence, Would-be criminals

\section{Introduction}

Punishment, death penalty inclusive, is the infliction of suffering upon an offender on the grounds of a particular crime committed and convicted of and administered by an authority so designed (Ferguson and Wright, 1988). Arikpo (1999) on his part sees it basically as, the subjection to strict rules of conduct, or the suffering or imposition of hurt or injury for some of some offence or hurt committed. Punishment usually takes any form; fine, penalty or confinement inflicted and sentence of the court of law, either for an offence committed by him or for his omission of a duty enjoined by law (Iwe, 1991).

It is needful to state here that no matter the form or kind, punishment takes; it is primarily geared towards the restoration of the ethico-judicial order abused or violated by crime. Over the years, society has always used punishment to discourage potential offenders from carrying out criminal activities. Capital punishment or as some would prefer, death penalty is as old as human society itself. Death penalty has been applied in almost every known society, as a form of sanction or punishment for clearly defined offences

In the last couple of years, the issue of death penalty has resurfaced in a number of national debates in Nigeria, thus calling for a revisit of the vexed and controversial issue. Over the years, 
many people have looked at death penalty as a very good way of deterring people from the commission of crime. In this wise, it is seen not only as the punishment of the offender but also the prevention of similar crimes. Unfortunately as Volpe (2002) puts it, death penalty does not in fact deter criminal acts, as most proponents of death penalty expect. When someone takes a life for instance, the balance of justice is disturbed and unless it is restored, society succumbs to a rule of violence. It is the taking of the offender's life too that restores the balance and allows society to convincingly show that crime intolerable and will always be punished in kind.

\subsection{Statement of the problem}

The concept death penalty has been and will always be a controversial issue. Most Nigerians have very strong opinions and arguments to support their sides of the divide. Interestingly, arguments for both sides can be extremely convincing but it must however be noted that these arguments boil down to personal opinions. As controversial as the issue of death penalty may be, it has been with the Nigerian society for centuries and wittingly or unwittingly, been accepted by the society, especially as it seeks to punish those who have committed an offence against the laws of the land

Recently in Nigeria, death penalty became a controversial topic especially against the background that the former president of the country Chief Olusegun Obasanjo throughout his tenure deliberately refused to acquiesce to death penalty. Several state governors were also very reluctant in signing the death warrant brought before them (Obarisiagbon, 2017). This is in spite of the fact that, Section 33(1) of the 1999 Constitution of the Federal Republic of Nigeria not only laid the ground for death penalty but also provided for its legality in Nigeria. The divergent views on death penalty, shows that its supporters see it as legal and a necessary action in order to protect the citizenry. They further contend that capital punishment is not only retributive but also acts as a deterrent to would be criminals in the society. On the other hand, anti-death penalty proponents are quick to argue that it is an inhuman act, and that there is never any justification for cruel and unusual punishment under any circumstance when involving the human life (Amnesty International, 1987).

On the surface, the arguments for and against the use of death penalty appear very compelling. However, just like the Holy Bible says, shall we continue in sin that grace may abound (Rom 6:1). In the same vein, should we abolish the use of death penalty because it involves the taking of human life and then allow the taking of lives by criminals? From the Nigerian experience there appears to be no studies and statistics that conclusively allude to the fact that death penalty deters the further commission of crime. In other words, the exact effect of death penalty for crime commission remains unknown. This study therefore seeks to determine the extent to which death penalty has helped to deter would be criminals from committing of crime in Nigeria.

\subsection{Objective of the study}

This study was designed to examine the extent to which death penalty deters would be criminals from committing crime in Southern Nigeria.

\subsection{Research question}

Does death penalty deter would be criminals from committing crime in Southern Nigeria?

\section{Brief Review of Related Literature}

\subsection{Meaning and nature of death penalty}

Death penalty is the execution of a criminal pursuant to a sentence of death imposed by a competent court of law (Idris, 2012). In other words, it is the legal possibility of execution (Azinge, 1990). The Oxford reference concise dictionary of law defines it as death imposed as a punishment for crime. It can also be referred to as execution of a person convicted of committing a crime or a 
legal infliction of death as penalty for violating criminal law (Iveren, 2012). On his part, Akingbehin (2012) has described death penalty as the prescribed treatment meted to an offender who has been found guilty by a court of competent jurisdiction of committing a capital offence. It is the most extreme form of punishment known in Nigerian law.

In traditional Nigerian society, certain offences like murder, adultery, witchcraft, profaning the gods or spirits were visited by death penalty. This was seen as the best way of eliminating offenders who were considered dangerous to the society. However, with the coming of the British rule in Nigeria, capital crimes were reduced to include only murder, treachery and treason. Section 319, 49 (a), 37 and 208 of the Criminal Code Act 2004, outline some offences as punishable by death penalty. More recently, kidnapping has been added as an offence punishable by death in Anambra, Abia, Imo, Delta, Edo and some other states in southern Nigeria (Obarisiagbon, 2017).

Section 33 (1) of the constitution of the Federal Republic of Nigeria did not only lay the ground for death penalty but also established its legality and this has received judicial backing in Okoro v. State (1998) and Adeniyi v. State (2000). Although the Nigerian laws recognize the use of death penalty on undesirable elements found guilty of committing capital offences, it must be pointed out quickly that there are however exceptions to this general rule.

\subsection{Exceptions to the general rule}

Section 365 (3) of the Criminal Procedure Act, (2004) provides that juvenile offenders under 18 years even though found guilty of committing criminal offences cannot be visited by the death penalty. This principle of law was further given judicial backing in the case of Modupe v. the State (1988).

The law in Nigeria specifically Section 368 (2) of the Criminal Procedure Act (2004) forbids the use of death penalty on a pregnant woman despite her being found guilty of committing a capital offence. The reason for this is perhaps due to the fact that the law considers the foetus in the womb of the offending women innocent and taking its life along with that of its mother would be unfair and a miscarriage of justice. In the same vein, Nigeria is under strict obligation not to execute women with nursing children. In other words, nursing mothers no matter the capital offence committed and convicted of, are exempted from the death penalty in accordance with the African convention on human and people's right protocol on the side of women.

The law in Nigeria also frowns at the use of death penalty on an insane or mentally ill person even though guilty of capital offence. Section 28 of the Criminal Code Act (2004) is very explicit on this and the general rule is that an insane or mentally ill person lacks the ability to make sound judgment due to his or her state of mental being and to execute such a person, is to put it mildly, wicked and a traverse of law.

\subsection{Modes of executing the death penalty in southern Nigeria}

In Nigeria, death penalty is usually carried out in two ways: hanging and shooting or firing squad. Section 37 (2) of the Criminal Procedure Act (2004) prescribes hanging as a method to be used in furtherance of a death sentence made against an offender by a competent court of law, while the latter refers to the method which was very common during the military era in Nigeria where convicted armed robbers are tied to the stake and military men selected for the purpose shoot them until they are certified dead by a medical practitioner.

\subsection{Argument for and against the use of death penalty}

The issue of the application of death penalty has been a subject of controversy with different scholars arguing for and against. Those who argue in favour of the application of death penalty are quick to say that as a retributive measure, the criminal should pay for the crime he has committed by death. In their opinion, to allow such a person go free, is to further endanger the lives of others. This argument stand on the ethical principle that evil deserves castigation and wrong doing deserves reparation by way of adequate deprivation and punishment for the offender (Iwe, 1991).

Uduigwomen (2005) has argued that the retention of the death penalty is because it acts as a 
deterrent to future infractions by those who witness the execution of a criminal. He contends further that death penalty is a deterrent or preventive measure designed to deter members of the society at large from committing capital offences. In this vein, it helps to protect lives and property and ultimately secures and protects social order and peace.

On the other hand, a lot of arguments have been raised against the application and use of death penalty in Nigeria. Human right proponents have argued that death penalty is a direct violation of the fundamental right to life and that its use is prone to abuse. The process leading to sentences may in fact not be free from error and fraud (Shapiro, 1998).

It has also been argued that the application of death penalty is indecent and de-humanizing. In Nigeria, condemned criminals in most cases are left to languish in jail and in some cases, completely forgotten. One can better imagine than attempt to describe the psychological trauma condemned criminals go through while awaiting the date of execution in the most de-humanizing and dilapidated condition of the prisons (Uduigwomen, 2005).

Donohue (2015) after an extensive comparative analysis between American states that have abolished death penalty and those that retained it or, in Hong Kong and Singapore came to the conclusion that there is not the slightest credible statistical evidence that death penalty deters criminals from committing capital offences. On his part, Radelet (2009), after a survey that had majority of the world's criminologists as participants, came to the conclusion that the death penalty does not add any significant deterrent effect above that of long term imprisonment.

Studies claiming that death penalty reduces crime, to Kovandzic, Vieraitis and Boots (2009) falls apart under close scrutiny and results provide no empirical support for the argument that the existence or application of the death penalty deters would-be criminals from carrying out capital offences.

\section{Theoretical Framework}

This study employed the functionalism perspective in the explanation of the topic under investigation. The theory holds that social phenomenon can be explained in terms of the part they play in the existence and survival of the larger society. It notes that there is inter-dependence of various parts within the system. This means that the function of a part of a system usually affects the system as a whole. Moreover, there is the need for the system to maintain equilibrium in order to survive. This means that the social system tend towards equilibrium. That is, when one variable of the system changes in magnitude or in quality, the other variables are subjected to strains and are transformed. As a result, the system changes its pattern of performance and the dysfunctional components are disciplined by a regulatory mechanism and the equilibrium of the system is reestablished (Parson, 1951).

In explaining death penalty, the functionalist perspective looks for how ideas or subject of the society works in consonance and the role each play to achieve the corporate goal of social order. Functionalism sees death as playing a very vital function in the stability and growth of the society by getting rid of undesirable elements through death penalty. In other words, the sustenance of death penalty in society ensures that undesirable elements- criminals are not only gotten rid of but ensures that they are no longer threat to the society.

Scholars like Montaldo (2010), have explained the death penalty using the functionalist perspective as playing a major role in ensuring that the prisons which are overcrowded are decongested. Nigeria's prison facilities are presently overstressed and death penalty when applied, functions as a 'decongester' thus creating more space and freeing resources. This, it does by indirectly saving money for the government by not needing to feed, clothe, guard and shelter the condemned.

\section{Methods and Materials}

The concurrent triangular design was adopted for the study in order to obtain different but complementary data on the same subject matter- death penalty. The choice of this design was to bring together the differing strengths and non-overlapping weaknesses of quantitative methods with those of qualitative methods (Creswell, 2004). From the qualitative paradigm, the descriptive survey 
design was used. The descriptive survey design was used to collect information that describes, explores and helped the study to investigate population based on sampling (Kothari, 2011). For the qualitative paradigm, the in-depth interview (IDI) and key informant interview guides were used since it is a purposeful undertaking by the study which interrogated subjects on a given situation to collect needed information. The face and content validity of the research instrument was ascertained by three experts in the field of criminology in Nigeria. The split-half method was used to determine the reliability of the instrument. Reliability coefficient result obtained for the instrument was .91. The data gathered through qualitative technique was content analyzed while descriptive and inferential statistics was used for the quantitative data.

A total of 1,215 respondents were purposively sampled while 30 in-depth interviews and 15 key informant interviews were conducted amongst respondents which consisted of police officers, legal practitioners, high court judges and director of public prosecutions' office in capital cities of Anambra, Delta and Edo states in southern Nigeria. The choice of these participants stemmed from the fact that they are very knowledgeable in the subject under investigation. Out of the one thousand two hundred and fifteen (1215) questionnaires that were administered, one thousand, two hundred (1200) were returned, found useful and therefore used for analysis. This however represents a return rate of $98.8 \%$ and is considered significant.

For the purpose of efficiency and thoroughness, three field assistants were recruited and trained. The field assistants were involved in the pre-test of the instruments and also the collection of the required data used for the study

\section{Discussion and Findings}

Demographic characteristics of the respondents are displayed in table 1.

Table 1: Demographic characteristics of respondents

\begin{tabular}{|l|c|c|}
\hline & Frequency & Percentage (\%) \\
\hline Age (Year) & & 37 \\
\hline $25-34$ & 446 & 30 \\
\hline $35-44$ & 358 & 31 \\
\hline $45-54$ & 366 & 3 \\
\hline $55-64$ & 30 & $\mathbf{1 0 0}$ \\
\hline Total & $\mathbf{1 2 0 0}$ & 69 \\
\hline Sex & & 31 \\
\hline Male & 830 & $\mathbf{1 0 0}$ \\
\hline Female & 370 & \\
\hline Total & $\mathbf{1 2 0 0}$ & 90 \\
\hline Religion & & 9 \\
\hline Christianity & 1080 & 1 \\
\hline Islam & 110 & $\mathbf{1 0 0}$ \\
\hline ATR & 10 & \\
\hline Total & $\mathbf{1 2 0 0}$ & 3 \\
\hline Marital status & & 96 \\
\hline Single & 41 & 1 \\
\hline Married & 1150 & $\mathbf{1 0 0}$ \\
\hline Divorced & 9 & - \\
\hline Total & $\mathbf{1 2 0 0}$ & 40 \\
\hline Educational level & & 60 \\
\hline Primary & - & $\mathbf{1 0 0}$ \\
\hline Secondary & 482 & \\
\hline Tertiary & $\mathbf{7 1 8}$ & \\
\hline Total & $\mathbf{1 2 0 0}$ & \\
\hline & & \\
\hline
\end{tabular}

Source: field survey, April 2017 - July 2017 
Table 1 summarizes the results of the demographic characteristics of the respondents. It shows that among the 1200 respondents who participated in the study, 37\% were in the $25-34$ years age range, $30 \%$ were between $35-44$ years while $31 \%$ were between $45-54$ years and $3 \%$ were between $55-64$ years. $69 \%$ were male while $31 \%$ were female while $90 \%$ of the respondents were Christians, $9 \%$ were Muslims and ATR was $1 \%$. On educational level, there was no primary school respondent, but $40 \%$ had secondary education while $60 \%$ had tertiary education.

Table 2: Death penalty and crime

\begin{tabular}{|l|c|c|c|}
\hline \multirow{4}{*}{$\begin{array}{l}\text { Does the death penalty deter would-be criminals from } \\
\text { committing crime? }\end{array}$} & Response & Frequency & $\begin{array}{c}\text { Percentage } \\
(\mathbf{\%})\end{array}$ \\
\cline { 2 - 4 } & Agree & 210 & 18 \\
\cline { 2 - 4 } & Disagree & 982 & 81 \\
\cline { 2 - 4 } & Undecided & 8 & 1 \\
\hline Total & & $\mathbf{1 2 0 0}$ & $\mathbf{1 0 0}$ \\
\hline
\end{tabular}

Source: field survey, April 2017 - July 2017

On the question, does the death penalty deter would-be criminals from committing crime? $18 \%$ of the respondents agreed that it does, while $81 \%$ disagreed and only $1 \%$ was undecided respectively. The finding of this study validates the previous studies of several scholars like Donohue (2015), Radelet (2009) and Kovandzic et al (2009) who were unanimous in studies that the application of the death penalty does not deter would-be criminals from carrying out criminal offences.

The finding of this study is further given credence to by one of the interviewees who unequivocally stated that:

"Personally, executing criminals whether by firing squad or hanging does not in any way make others not to commit the same offence. After all, Evans the billionaire kidnapper knew that kidnapping in Edo, Delta and Anambra is punishable by death yet he kidnapped several victims and carted away millions of naira". (IDI Legal practitioner, Asaba, Delta state)

Another interviewee simply puts it thus:

"In my several years of sitting on the bench, I have come to realize that some criminals are so hardened that death does not mean a thing to them ".(KII High court judge, Benin City, Edo state)

A police officer in his own opinion stated that:

"These criminals do not believe that they will ever be caught in their criminal acts. Once they take 'weed', Indian hemp or other stimulants, they become emboldened and daring and so go out to maim, kill and commit havoc " (IDI Police inspector, Awka, Ananmbra state)

In the same vein, another interview was very blunt when he said that:

"It appears that some persons no matter the punishment you mete out to them, will still continue to do the same thing over and over. Not even the pains afflicted on them or the fear of death can discourage them from their evil act". (KII Counsel in the office of the Director of public prosecution (DPP), Benin City, Edo state)

\section{Conclusion and Recommendations}

The global trend now appears to be the abolition of death penalty. A majority of countries in the world has now abandoned the use of the death penalty even though the world has not yet formed a consensus against its use. Interestingly, the number of countries that still use it is declining (Amnesty International, 1987) and it is hoped that the world wide opinion and pressure against it will gradually influence other nations to jettison this unprofitable practice. 
It is suggested that government rather than eliminating criminals should instead focus more on their rehabilitation. Their death does not serve any useful purpose for the state and is generally against the ideals of restorative justice.

There has been intense pressure in recent times on the Nigerian government to review the law on death penalty. There is the need therefore to subject the issue to public debate to enable Nigerians express their views on it. In addition, both the federal and state ministry of justice should convey a study group on this controversial issue. It is hoped that findings from such study groups will in no small way assist the relevant government agency in developing an appropriate policy on the death penalty.

There is also the urgent need for government to use its enormous power and resources to redress some of the inequalities and injustice that characterize our society. Without doubt, a strong link exist between taking the social and economic needs of the citizens seriously and a low crime rate.

Studies have revealed that convicted criminals do feel strong remorse for what they have done (Volpe, 2002). To err is human, to forgive is divine and so, the Nigerian legal system should require inmates to meet with counselors or spiritual leaders and possibly work to pay their debt to the society while still in prison. Taking their lives further brings pain to their own family and dependants without necessarily compensating the victims' life or that of his family and dependants.

Death penalty undermines rather than witnesses to the sacredness of human life and is completely out of step with current standards of decency.

\section{References}

Adeniyi v. the State (2000) 645 NWLR 356

Akingbehin, E.O. (2012). Exceptions of the vulnerable from capital punishment in Nigeria: expanding the frontiers. In British Journal of Arts and Sciences, 7 (1)

Amnesty International (1987). United States of America: death penalty 228 (appendix 12)

Arikpo, A. (1999). Pursuant and responsibility in Uduigwomen, A.F. and Ogbonaka, O. (eds) in Philosophy and Education. Lagos, Obaro and Ogbinaka Publishers Ltd.

Azinge, E. (1990). The death penalty: an effective deterrent to drug trafficking and abuse? In B. Ajibola (gen.ed), Kalu, A.U. and Osinbanjo, Y. (eds), narcotics: law and policy in Nigeria, 8 (Lagos: Federal Ministry of Justice Law Review Series).

Constitution of the Federal Republic of Nigeria, 1999

Creswell, J. W. (2004). Advanced mixed methods research design. In A. Tashakkori and C. Teddlie (Eds), handbook of mixed methods in social and behavioural research. Thousand Oaks, CA: Sage.

Criminal Code Act (2004) Cap C. 38 Laws of the Federation of Nigeria

Criminal Procedure Act (2004) Cap 41 Laws of the Federation of Nigeria

Donohue, J. (2015). There is no evidence that death penalty is a deterrent against crime. Available at: http://www.theconversation.com (accessed on the 8 August, 2015).

Ferguson, S. B. and Wright, D.F. (Eds) (1988). New dictionary of theology. Leicester: Inter Varsity Press.

Holy Bible, Romans 6.1.

Idris, T.A. (2012). Capital punishment and its effect on Nigerian criminal law. Available at: unijos.edu.ng/../234244pdf232@233 (accessed from 17 $7^{\text {th }}$ of August, 2012).

Iveren, O.B. (2012). Justification for the abolition of capital punishment under human rights law. Available at: www.unilorin.edu.ng/..I (accessed on $18^{\text {th }}$ July, 2012).

Iwe, N.S.S. (1991). Socio-ethnical issues in Nigeria. Oruwulu-Obosi, Pacific Publishers.

Kothari, C.R. (2011). Research methodology. New Delhi, New Age International Limited.

Kovandzcic, T., Vieraitis, L. and Boots, D. (2009). Does the death penalty save lives? New evidence from state panel data, 1977-2006. In Journal of Criminology and Public Policy, 8

Modupe v. the State (1988) 4 NWLR (P.T 87-130).

Montaldo, C. (2010). U.S prisons- how crowded are U.S prisons. Available at: http://www.aclu.org/capitalpunishment/race-and-death-penalty- (accessed on Wednesday, November 3, 2010).

Obarisiagbon, E.I. (2017). Kidnapping and the administration of criminal justice in selected states in Nigeria. Unpublished Ph.D dissertation, University of Ibadan, Ibadan, Nigeria.

Okoro v. the State (1998) 14 NWLR 584

Parsons, T (1951). The social structure. London, The Free Press of Glencoe.

Radelet, N.L. (2009). Do executions lower homicide rates: the views of leading criminologists. In Journal of Criminal Law and Criminology. 99 (1), 489-508 
Shapiro, J.P. (1998). The wrong men on death row. United States of America news and world report. Uduigwomen, A.F. (2005). "Studies in philosophical jurisprudence" $2^{\text {nd }}$ ed. Calabar, Jochrisam Publishers.

Volpe, T. (2002). Capital punishment: does death equal justice. Available at: http://www.jmu.edu/evision (accessed on the $24^{\text {th }}$ April, 2002). 